\title{
Features Of Using The Modern Software For Thermal Field 3D Modeling
}

\author{
V. Fourman \\ Head of department Physics of the Earth \\ Ivan Franko National University of Lviv, Hrushevskij Str. 4, \\ $U A-79005$, Lviv,Ukraine \\ e-mail: fourman@i.ua
}

\begin{abstract}
Interrelation of tectonic activity with a thermal stream, stratygraphy and lithology of Beregovo district of Transcarpathian is examined. Materials of Geology party of Beregovo and regime geophysical station (RGS) of Beregovo are executed. Three-dimensional models of thermal field, stratigraphic and lithologic ones ware created
\end{abstract}

Index Terms-thermal stream, tectonic activity, design, environment

\section{INTRODUCTION}

Increasing the informativeness of geophysical methods using potential fields (primarily gravity and magnetic) in the study of the Earth's interior is associated with attempts to obtain a layered distribution of physical properties of rocks, that is to divide the source of the fields vertically. It is obvious that in the general case, solving the problem of dismemberment of the geological section vertically according to the data of gravimetry and magnetometry is fundamentally impossible [1-5]. However, the necessity of obtaining three-dimensional distributions of density and magnetization of rocks is dictated by the practice of geophysical works, the complication of geological problems, the high degree of development of resources, etc.

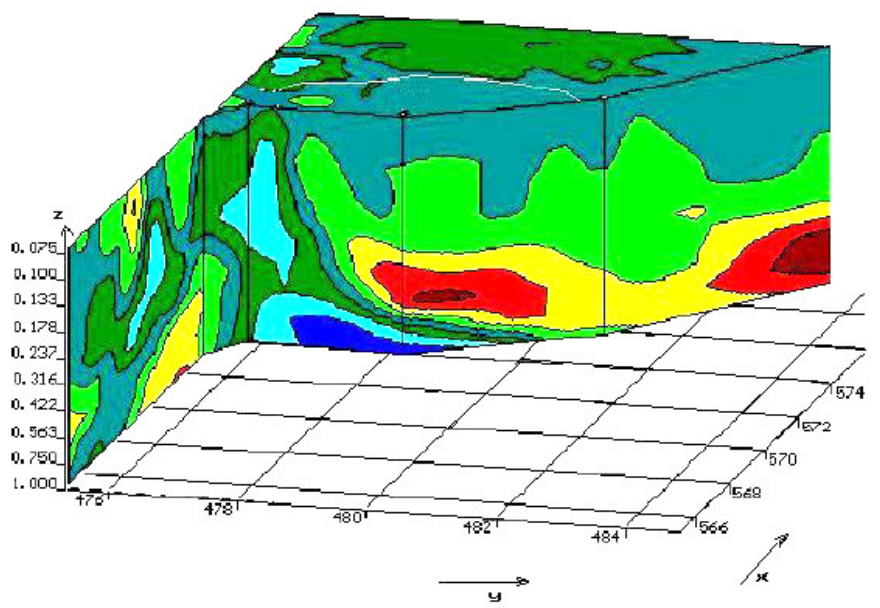

Fig. 1. 3D diagram of geological structures in a gravitational field [7].

\author{
D. Malytsky \\ Head of Department of seismotectonic research methods \\ Carpathian branch of Subbotin institute of geophysics 3-6 \\ Naukona st., 79060, Lviv,Ukraine \\ e-mail: dmytro@cb-igph.lviv.ua
}

\section{THREE-DIMENSIONAL GEOLOGICAL AND GEOPHYSICAL MODELS}

The joint application of the system of vector scanning, gravitational modeling and correlation analysis enables to construct a geological model that is adequate to the a priori geological information and the observed field. Therefore, in view of the known theoretical limitations, using some properties of potential fields and a priori geological information, in recent years, fundamentally new methods of interpretation of fields with the aim of constructing a threedimensional model of the structure [3-7] of the geological environment that are adequate to the observed field and available a priori information are intensively created. One of the main advantages of tomographic systems, which determined their great need for the practice of geophysical works, is the possibility of obtaining a three-dimensional picture (Fig. 1) of the distribution of physical properties of rocks and localizing the sources of anomalies in space.

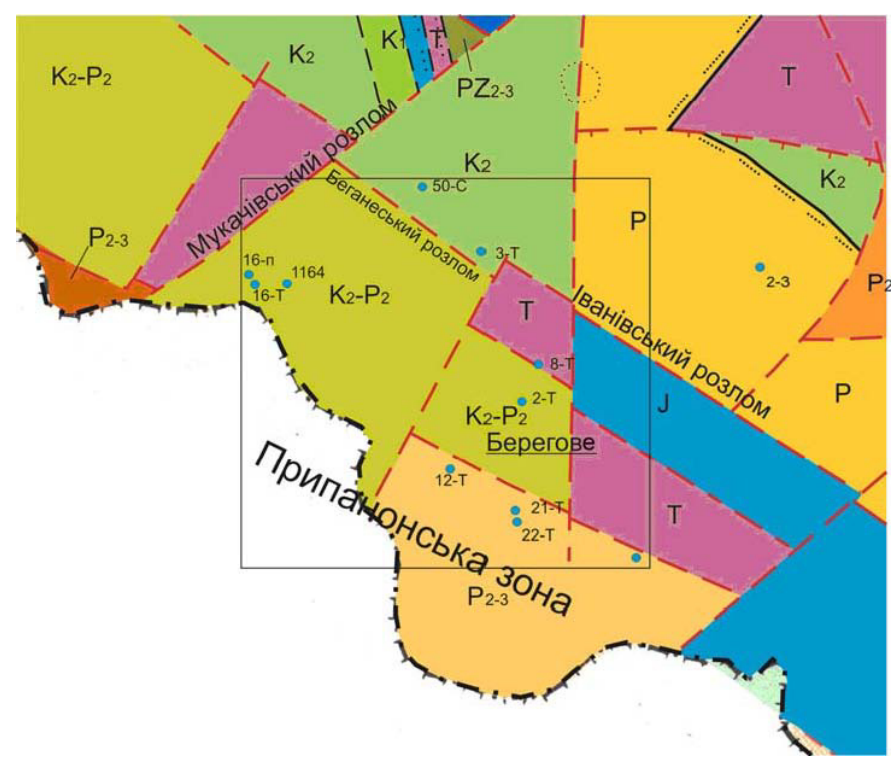

Fig. 2. Geological map of the studied area

Such methods include interpretive tomography, frequency selection, correlation sounding, compensatory filtration, as well as methods based on analytical continuation of fields, layer density determination, etc. Interpretation of potential fields using a priori geological information enables to successfully 
solve complex geological problems, to determine the depths of occurrence of sources of anomalies and to identify them with geological objects of a specific given form.

The geological history of the Carpathian region has not yet been fully elucidated, which can not but affect, for example, the nature of the thermal field. We will pay attention to the problem of the relationship between tectonic activity and the thermal regime of a specific block in the Transcarpathian region. The purpose of these studies, on the one hand, is the development of the methodology, on the other hand, the study of the relationships between the temperature field and the tectonic processes occurring in the earth's crust. In addition, based on data from wells, we will try to construct 3D stratigraphic and lithological models of the explored block. Accumulation of tectonic energy in the bowels of the Earth causes a number of violations of the isostatic equilibrium of the earth's crust, vertical and horizontal displacement of lithospheric plates and blocks [8]. Thus, processes of tectonic and thermal activation are related to each other and can be compared with the dynamics and structure of the crust at the regional and local levels. Our task is to construct 3D models of geological and physical environments for the study of the relationship between tectonic activity and thermal flow, stratigraphy, and lithology of a particular region. The explored models cover the territory of the city of Berehove and adjoining territories measuring $18 \times 18 \mathrm{~km}$ (Fig. 2). We will use data collected from 13 wells with depths of 900-1600 m, namely:

- characteristics of the lithospheric composition of rocks;

- $\quad$ age data of breeds;

- temperature data at different depths.

Conducting geodynamic research in the Carpathian region of Ukraine is an extremely important task, because increased seismic activity has been observed on its territory. It is known [10] that the geostructures of this region are quite complex, different in structure and intensity of tectonic processes. Tectonic faults are important in creating a modern geological structure in Transcarpathia. Many tasks of fracturing tectonics of the Carpathians, in particular, such as the current activity of faults, their reflection in the relief, have not yet been sufficiently studied. Complex geological and geophysical studies can answer these questions. The dynamics of the earth's crust and its thermal state are closely interconnected, due to the nature of deep tectonic processes. To understand the interconnection of various natural fields of the Earth, many scientists model geological and geophysical environments using modern computer software [9].that anticipate your paper as one part of the entire proceedings, and not as an independent document. Please do not revise any of the current designations.

\section{3D MODEL OF THERMAL FIELD}

Thus, the analysis of global tomographic models makes it possible to conclude that the temperature distribution in the upper mantle (on the structure of the thermal roots of the continents) without the interpretation of the data on the heat flux. The generalization of the latest results of seismic, gravitational and thermal studies of continental roots makes it possible to state that seismic tomography remains the only method that gives a spatial picture of the upper mantle. According to the results of the analysis, three-dimensional models of the thermal field of the investigated block were constructed for the temperature readings of 13 wells, shown in Fig. 3, a, b, 3. In Figure 4 shows the thermal field models of the cuts: N-S, E-W, NE-SW, NW-SE. From the obtained models it can be concluded that the heat flow increases in the direction of south-north, which coincides with the Mukachivsky and Begansky.

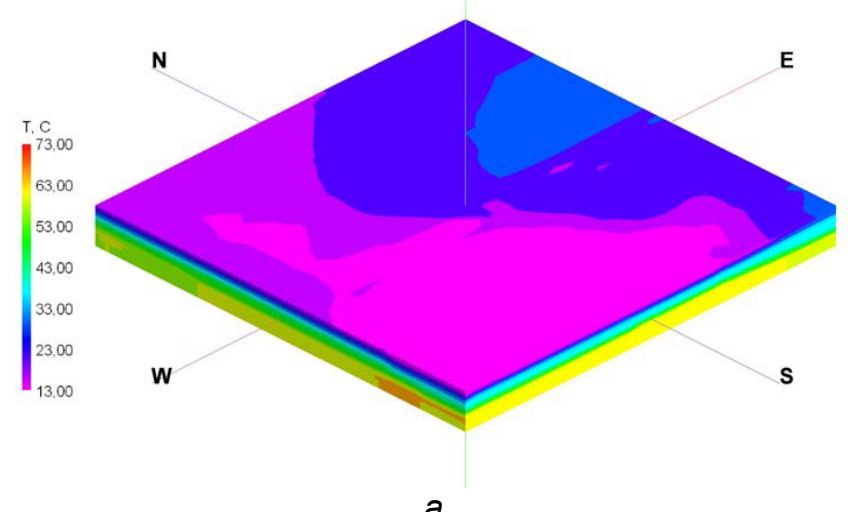

a

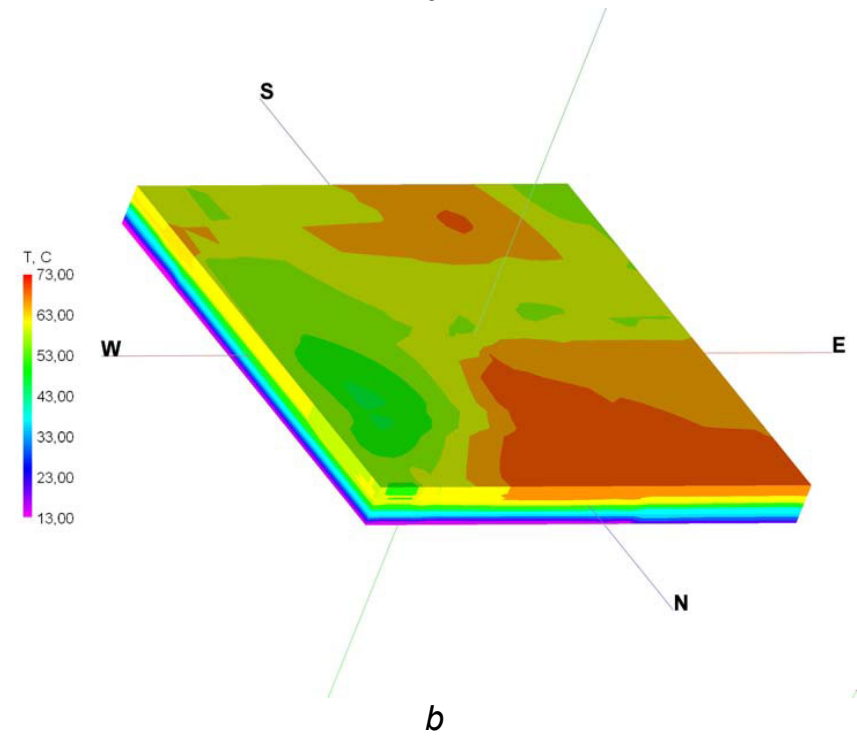

Fig. 3. 3D model of the thermal field: $\mathrm{a}$ - the view from above; $\mathrm{b}$ - the bottom view.

The temperature mode of the investigated block is related to its structure. More detailed research is planned to be carried out in the future using the data of the temperature regime of the study area at the regime geophysical station (RGS) "Beregovoe". Today, this CSG is constantly monitored for changes in the temperature field at different depths, as well as deformation observations using a laser logger. The basis of such works is geotravers of deep seismic sounding, using additional information, which limits the range of possible solutions of the inverse problem of gravimetry. Specificity of the used interpretation techniques does not allow to directly compare the results obtained for different structures. In 
particular, density variations are always determined in relation to some "standard" model, which can vary widely. Even a simple comparison of the average density of the continental and oceanic mantle is still a problem. Thus, only a global study by a single method allows comparative analysis of isolated structures. It is known that the use of only a gravitational field without additional information does not allow us to obtain a reliable result. Global three-dimensional images of the internal structure of the Earth, created on the basis of variations in the velocities of seismic waves, have become one of the main achievements of geophysics of the last decade

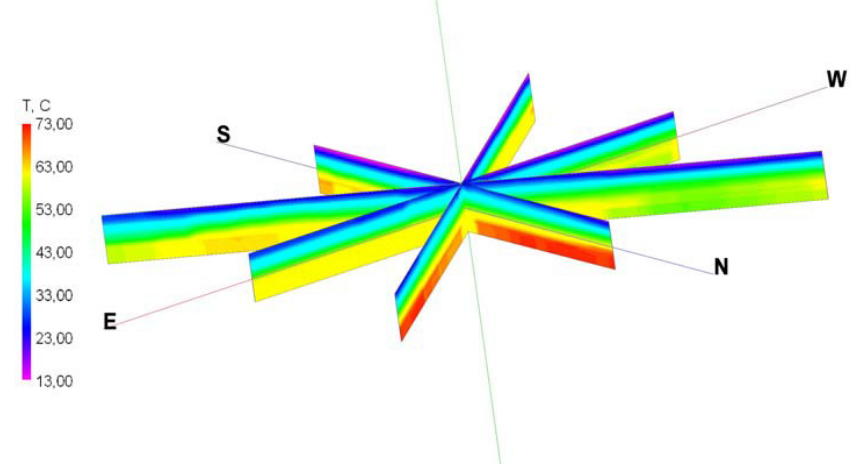

Fig. 4. 3D model of thermal field (view in a section).

In fig. 5 depicts the 3D lithological model of the investigated region. According to the lithological composition of the blocks of the block, we divided it into three packs:

- 0-100 m - sedimentary rocks of various lithological composition (sand, sandwiches, aleurolites, argillites, clay);

- 100-950 m - floodplain of sedimentary and volcanogenic rocks (tuffs, tufahrillites, ingimbrites, lyrparts, and liparite tuffs);

- $950 \mathrm{~m}$ - sedimentary rocks of different lithological composition (sand, sandwiches, aleurolites, argillites).

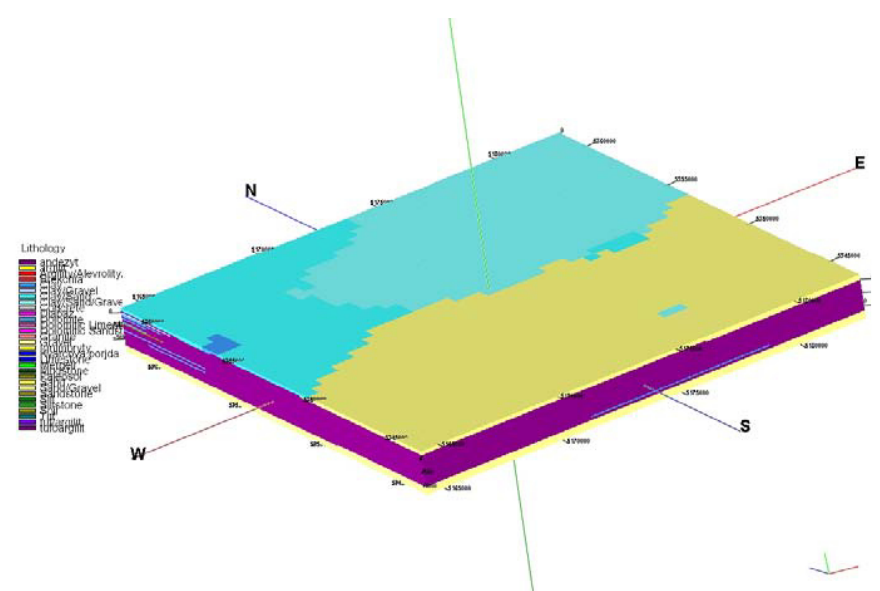

Fig. 5. 3D-lithological model, top view.
This area during the Neogene period was subjected to uneven lowering to the Neogene blocks, which affected the formation of Neogene rocks. In the central part of the investigated area, the horizontal occurrence of rocks (Berehovo tectonic block) and sites with inconsistent occurrence, wedging (see Fig. 2) [8] are revealed.

\section{ACKNOWLEDGMENT}

Thus, according to the obtained results, it was determined that the temperature regime of the investigated block of Transcarpathia (a square $18 \times 18 \mathrm{~km}$ in the district of Berehove) is interrelated with the structure and tectonic processes of the region. According to 13 wells, it was found that the heat flow is increasing in the south-north direction, which coincides with the Mukachevo and Begansky faults. It is clear that such studies should be carried out in the future for other blocks of the region in order to obtain a more complete picture of the dependencies of different geophysical fields on the tectonic activity occurring in the earth's crust.

This block is composed primarily of volcanic materials brought from the VigorLat-Gutinsky volcanic strand. The use of stratigraphic and lithological models only complements and confirms the described interrelation.

\section{REFERENCES}

[1] Woodhouse J. H., Dziewonski A. M. Mapping the upper mantle: Threedimensional modeling of Earth structure by inversion of seismic wave forms // J. Geophys. Res. - 1986. - Vol. 86. - P. 5953 -5986.

[2] Dziewonski A. M., Woodhouse J. H. Global images of the Earth's interior // Science. - 1987. - Vol. 236. - P. 37 -48. 21

[3] Dziewonski A. M., Anderson D. L. Preliminary reference Earth model // Phys. Earth Planet. Inter. - 1981. - Vol. 25. - P. 297 -356.

[4] Dziewonski A. M., Hales A. L., Lapwood E. R. Parametrically simple models consistent with geophysical data // Phys. Earth Planet. Inter. 1975. - Vol. 10. - P. $12-48$

[5] Grand S.P., Van der Hilst R. D., Widiyantoro S. Global seismic tomography: a snapshot of convection in the Earth // Geol. Soc. Am. Today. - 1997.- Vol. 7. - P. 1 -7. 30.

[6] 11. Masters G., Laske G., Bolton H., Dziewonsli A. M. The relative behavior of shear velocity, bulk sound speed and compressional velocity in the mantle: implications for chemical and thermal structure // Geophys. Mon. - 2000. - № 117. - P. $63-87$.

[7] Бычков С.Г. Современные технологи и интерпретации гравиметрических данных при исследованиях на нефть и газ // Нефтегазовое дело, 2005. - Режим доступу: http://www.ogbus.ru

[8] Венглинський И.В., Городецький В.А. Стратотипы миоценовых отложений Волыно-Подольской плиты, Передкарпатского и Закарпатского проги-бов. К.: Наук. думка, 1979. 174 с.

[9] Лазаренко Э.А. По вулканическим Караптам: Путеводитель. Ужгород: Карпаты, 1979. 95 с.

[10] Максимчук В.Ю., Кузнєцова В.Г., Вербицький Т.3. та ін. Дослідження сучасної геодинаміки Українських Карпат. К.: Наук. думка, 2005 